\title{
A GLOBAL TUG OF WAR: A TOPOGRAPHY OF MICRO-BUSINESS FINANCING
}

\author{
LOUISE GULLIFER ${ }^{*}$ AND IGNACIO TIRADO**
}

I

INTRODUCTION

Micro-businesses are the lifeblood of any functioning economy; they are more numerous and, collectively, have a higher turnover than any other form of business in the majority of countries around the globe. In all parts of the world, developed and underdeveloped, however, they are starved of finance, and the finance that is available is often on unsuitable and unsatisfactory terms. This article maps out both the reasons for this phenomenon and particular problems caused by the unique characteristics of micro-businesses, and suggests some legal and institutional responses. Some responses are designed to increase access to finance for micro-businesses by proposing measures to eliminate barriers, decrease costs, and increase lender certainty. Others, however, are suggested in order to protect the borrowers, because, by their nature, micro-businesses are vulnerable to abuse of bargaining power, and, since many of the risk-takers are individuals, lack of protection leads to social problems. These two rationales for legal response are in direct tension with each other, in that a legal response designed to achieve the former usually cuts across the aim of the latter and vice versa. Without an appropriate balance being reached, changes designed to facilitate the financing of micro-businesses can either become so oppressive that the very people the changes are designed to assist fail to thrive economically or socially, or may go too far towards protecting the borrowers and fail to increase access to credit. The actual decisions as to the appropriate balance are, of course, a matter of policy and will vary from state to state, depending on many factors. This article merely seeks to identify responses and the resulting tensions, and to begin to map out a framework for achieving that appropriate balance.

Copyright (C) 2018 by Louise Gullifer and Ignacio Tirado.

This article is also available at http://lcp.law.duke.edu/.

Q.C. (Hon), Professor of Commercial Law, Oxford University, Fellow and Tutor in Law, Harris Manchester College, Oxford, Holder of 2017 Santander Chair of Excellence at Universidad Carlos III de Madrid, during which time this article was written.

** Prof. Dr. Ignacio Tirado is a member of the Faculty of Laws, Universidad Autónoma de Madrid. 
II

\section{THE SCOPE OF THE ARTICLE}

It is first necessary to define what is meant by the term 'micro-business' in this article. Three measures are commonly used to define a very small business: the number of employees, the value of the business assets, or the turnover of the business. In this article, the World Bank's definition of a micro-business is used, namely an enterprise with not more than four employees. This includes both informal businesses and registered micro-businesses. ${ }^{1}$

Micro-businesses usually take one of two legal forms: either a legal entity, with or without limited liability, often involving registration and some formalities, ${ }^{2}$ or a sole entrepreneur. ${ }^{3}$ This latter phrase refers to an individual operating a business in his own name, either with or without employees. Whichever legal form the micro-business takes, the individual who runs it is exposed to financial risk, either as a sole entrepreneur or as a guarantor of the debts of the legal entity of which he is the director.

The vast majority of businesses in every country and globally are microbusinesses. For example, in 2011, 91\% of all Micro, Small, and Medium Enterprises ("MSMEs"), which includes enterprises with 250 employees or fewer ${ }^{4}$ were micro-businesses, while in developing economies, the figure was $93 \% .{ }^{5}$ Not only are micro-businesses important in terms of numbers, it is critical that they thrive for any economy to grow. This is because almost all enterprises start off as micro-businesses: they are the way that innovation and entrepreneurism flourish in an economy. Moreover, micro-businesses tend to be started, and run by, the young, marginalized groups such as women or minorities, and those who have lost jobs. Thus, encouraging micro-businesses has an important social as well as economic function.

There is, globally, a severe problem of lack of availability of finance to microbusinesses. ${ }^{6}$ Over 200 million micro-businesses in the world were "unserved," that is, they needed credit but had no access to credit, or "underserved," that is, they had a loan or a line of credit but were constrained as to the amount of available financing. ${ }^{7}$ The types of finance available are also very limited. Bank finance is rarely available, and most micro-businesses operate on very limited

1. See IFC Enterprises Finance Gap Database: Methodology, SME FIN. FORUM, http://www. smefinanceforum.org/data-sites/ifc-enterprise-finance-gap [https://perma.cc/MZ4U-D444] (last visited Nov. 6, 2017).

2. Some jurisdictions have introduced a simpler corporate form for micro-businesses, in order to reduce the costs of incorporation. See, for example, an explanation of the Colombian Sociedad por Acciones Simplificada in Francisco Reyes, The Colombian Simplified Corporation: An Empirical Analysis of a Success Story in Corporate Law Reform, 4 PA ST. J. L. \& INT'L AFF. 392 (2015).

3. This article uses this term, but other terms are also commonly used, such as "individual merchant" in civil law jurisdictions and "sole trader" in common law jurisdictions.

4. See IFC Enterprises Finance Gap Database: Methodology, supra note 1.

5. See IFC Enterprise Finance Gap Database: Data, supra note 1.

6. See IFC Enterprises Finance Gap Database: Methodology, supra note 1.

7. See id.; IFC Enterprise Finance Gap Database: Media, supra note 1. 
equity finance plus trade credit, that is, credit provided by suppliers of goods and services. In addition, where available, they rely on Government backed schemes, such as lines of credit and guarantee schemes, and some local assistance, such as guarantee schemes that associations of micro-businesses and chambers of commerce create. The next part of this article provides a more detailed discussion of debt financing options available in the private sector to micro-businesses.

III

\section{AN OVERVIEW OF THE FINANCING OF MICRO-BUSINESSES}

\section{A. Types of Finance for Micro-Businesses}

Micro-businesses may access finance in a number of ways. Equity financing is very rarely sufficient, equipment is often acquired using asset finance, and trade credit may also be relied on once the business has been established. However, this article does not focus on these types of financing, because problems specific to micro-businesses are not so acutely present in these areas. In terms of cash flow lending, micro-businesses mainly resort to two types of finance providers: banks or micro-finance institutions. Access to finance from banks presents a number of problems, identification of which constitutes the main bulk of this article, and which will be analyzed in detail in the following parts. ${ }^{8}$ The analysis essentially focuses on how to adapt standard banking machinery to the financing requirements of the smallest borrowers. Micro-finance institutions, briefly described in the next part, are, however, entirely different. This type of finance is an alternative to the general use of the financial system, but a limited one for various reasons. First, it involves very small debtors, borrowing very small amounts; secondly, it has a strong social component; thirdly, the risk assessment methodology, credit monitoring, and collection methods are uniquely adapted to certain types of businesses and communities; and fourthly, because it mainly thrives in developing nations. Spreading its use as a solution to the lack of access to finance is not a realistic possibility.

\section{B. Main Elements and Problems of Micro-Financing Institutions}

Because of their size and their cost structure, there is a limit to how far down the lending market banks are able to go: the smallest, most informal, most unsophisticated, micro-businesses that require small loans and have little or no collateral to offer, often find themselves outside that market. A special type of financial institution, often unregulated or only subject to basic regulation and low intensity supervision, and frequently non-deposit-taking, exists to fill the gap. Micro-finance institutions have flourished in developing and middle income economies, operating either as private financial businesses or under the auspices of Governments or international donors and financial institutions. ${ }^{9}$ Their goal is

8. See discussion infra Parts IV.B., IV.C.

9. See The World Bank Group and Microfinance, INT'L FIN. CORP., http://www.ifc.org/wps/wcm/ connect/industry_ext_content/ifc_external_corporate_site/financial+institutions/resources/the+world+b 
not just to make a profit: they tend to have a strong social component, financing sectors of society traditionally excluded from market practice, such as women, contributing to the education of the population, and helping to develop local markets.

The target clients of micro-finance institutions are mostly individuals with very low incomes and very limited means. They possess no, or very few assets to provide as collateral. Their activity is conducted in an informal manner, with little or no financial information available for lenders and they are often, despite the efforts of international financial institutions, not included in the scope of credit reporting systems. There is, thus, very limited financial information available for lenders. Although some borrowers have businesses in cities, much of the activity is rural, and tends to be widely spread out in the countryside, especially in countries where infrastructures are deficient. Micro-finance institutions are willing to lend small, or very small, amounts to be repaid in a very short period of time. The financial instrument most widely used is the (short) term loan, and, unless the government or international donors support the micro-finance entity, ${ }^{10}$ interest rates tend to be high or very high.

Micro-finance institutions operate in a manner based on classic relationship banking, adapted to the circumstances of developing countries. The decision to lend is made locally, by local people who are physically close to borrowers, whom they often know personally. It is taken based on the repayment capacity of the borrower and on his business plan (or rather, on a basic projection of his short term future revenues). The assessment of the plan is done personally, and hence it is costly and often slow. Monitoring takes place through direct contact, which is frequent and regular. Although loans are almost inevitably short, or very short, term, the underlying business model is to establish a stable lending relationship: replacing one loan with the next, repeatedly, so as to help the business to grow. This long-term relationship approach works, in a way, as a form of security: the more loans are repaid, the more certain it is that the debtor is reliable and worthy of future support. This, in turn, lowers the transaction costs, makes financial accounting less relevant, and the micro-finance entity's decision-making process becomes more nimble and streamlined. It also means that collateral is not often required.

Sometimes, especially when larger amounts are at stake, micro-finance institutions promote group lending. Several micro-businesses group together to

ank+group+and+microfinance [https:/perma.cc/JA7T-LGXL] (last visited Nov. 6, 2017) (explaining the leading role of the World Bank, and, in particular, the International Finance Corporation, in microfinance activity).

10. "Official sector" support may take different forms. Sometimes micro-finance institutions themselves are run by the government institutions or international donors; more frequently support takes the form of guarantee schemes, whereby a public or an international entity guarantees, in whole or in part, the loans provided by micro-finance institutions so as to lower the price. Another possibility is the setting up of funds or the provision of large amounts of money to banks, which will in turn create microfinance entities to lend out these funds. This, then, combines development subsidies with the expertise of private financial professionals. 
receive the funds, for which they will usually be jointly liable. This type of lending drastically reduces the danger of moral hazard, as well as reducing monitoring costs, because each borrower monitors the others. Where these types of lending schemes, either group or individual, operate, communities tend to be small and everyone knows one another. The preservation of reputation is therefore a very important incentive to repay the loan. Being shamed within the community is considered, in many rural areas, a hazard that must be avoided at all costs. These factors explain why the percentage of non-performing loans ("NPLs") in the micro-finance industry tends to be low-usually lower than the level of NPLs in the rest of the financial sector in the jurisdiction.

Micro-finance institutions have also been subject to stark criticism. Privately run entities frequently charge very high interest rates. All too often these institutions are unregulated and unsupervised, and abuses happen. Further, there is a line of economic thought contending that overall numbers show that microfinance does not help countries develop, because businesses set up with this money are too basic, often repetitive, and have little or no added value, and the use of resources in these unviable businesses deflects capital that would otherwise be available for consumption. ${ }^{11}$ In any case, and although it seems difficult to deny the positive effects that micro-businesses have had in the societies of developing nations, this sort of financing of micro-businesses is limited in scope and cannot be taken as a general mechanism for access to finance in the more developed jurisdictions, where the problem of access to finance also exists. However, certain elements of the micro-finance system, such as personal assessment of viability and regular monitoring, should also be features of bank lending to micro-businesses.

IV

\section{THE GEOMETRY OF LENDING TO MICRO-BUSINESSES}

\section{A. Introduction}

This section purports to analyze the different stages in the financing of microbusinesses, covering the entire life-cycle of credit and identifying the main problems that arise in each phase: the origination of credit (that is, access to finance), the development of the financing relationship between a micro-business and a financial institution, and the termination of the financing operation, with special reference to the problems arising on the verge of insolvency and once default has occurred. This article will focus on debtors and creditors, and consider the problems from an ex ante and an ex post perspective.

11. See generally DAVID ROODMAN, DUE DILIGENCE: AN IMPERTINENT INQUIRY INTO MicrofinANCE (2012); Milford Bateman \& Ha-Joon Chang, Microfinance and the Illusion of Development: From Hubris to Nemesis in Thirty Years, 1 WORLD ECON. REV. 13 (2012) (presenting a well-documented, albeit controversial, critical analysis of micro-finance). 


\section{B. The Origination of Credit}

\section{The Information Problem}

One of the main reasons for the unavailability and high cost of finance for micro-businesses is that such businesses are often unable to provide adequate financial information at the time they apply for a loan. This is especially true for informal micro-businesses: unincorporated businesses or other businesses that operate actively in the market without being registered in a business registry or with tax authorities. ${ }^{12}$ However, this is also true for some formal but very small businesses. Micro-businesses often do not file financial accounts, even if required to do so; moreover, many do not prepare financial accounts in a manner that sufficiently reflects their annual result and financial situation. There are various reasons for this. Those running the business do not see the need to do so because their business activity is very simple; they have few sources of income and creditors, a limited number of repetitive operations, and no or very few employees. Frequently, the business activity involves family members, so professional and family assets are not strictly separated. Moreover, those running micro-businesses lack the expertise to draw up financial information. The lack of adequate accounts is one reason why lenders do not assess the viability of potential borrowers on a case-by-case basis. ${ }^{13}$ Instead, they either make lending decisions on limited, standardized information, using other means to protect themselves,${ }^{14}$ or they just do not lend at all. The lack of insistence by lenders on proper financial information contributes to the existence of an untaxed economy, to the detriment of the public interest.

This information problem can be tackled in a number of ways. The best time to deal with it is when credit is originated. At this point, the debtor has the greatest incentive to produce and transmit sound financial and business information requested by the lender, because if it does not, no finance will be forthcoming. Banks are under a general duty to conduct proper risk assessments, in fulfillment of which they should require simple, but accurate, accounts to be produced by micro-businesses as a condition of considering their applications for loans. Of course, micro-businesses should not be required to keep complicated records or to produce complex financial statements. As in everything else concerning access to finance, a balance needs to be struck. Although microbusinesses must be required to produce sufficient and adequate financial information, this should be in a simplified manner to avoid overburdening businesses that have few personnel and limited material resources. ${ }^{15}$ Requiring

12. The degree of informality tends to be higher with the lower the level of economic development of the jurisdiction. See IFC: Enterprise Finance Gap Database: Media, supra note 1. According to a World Bank Group report, by October 2013, about $80 \%$ of all businesses in developing nations were either informal or had no employees. See id.

13. See discussion infra Part IV.B.2.

14. See infra Parts IV.B, IV.C, IV.D.

15. See 2015 IFRS for SMEs, IFRS, http:/www.ifrs.org/issued-standards/ifrs-for-smes/ [https:// perma.cc/U58X-X3KM] (last visited Nov. 6, 2017) (announcing information sharing standards for small 
this information is only a solution if the potential borrowers are honest. The existence of objective reservoirs of credit information, accessible to all lenders, is also critical. Credit reporting systems, including credit registries, credit bureaus, and commercial credit reporting entities, if adequately designed, can provide information which is very relevant to assessing the risk of lending. ${ }^{16}$ These systems should include information from as many sources as possible, going well beyond credit records from financial institutions. Most micro-businesses also obtain credit from suppliers and utility companies, and information from, particularly, the latter should be included in the credit reporting systems. Further, credit reporting systems should include positive, and not just negative, credit information, as well as information about the behavior of company owners and directors because, in the case of micro-businesses, the decision to lend will often depend on the credit history of the owner as well as the characteristics of the legal entity. ${ }^{17}$ Furthermore, the systems' information should be accessible to every possible credit provider, not only to financial institutions as is often the case. ${ }^{18}$

\section{The Costs of Assessing Risk}

As mentioned above, when deciding whether to lend to micro-businesses, banks do not always conduct proper, case-by-case, risk assessments based on the viability of the potential borrower. ${ }^{19}$ There are economic reasons for this, in addition to the lack of information discussed in the previous section. The small, or very small, size of the loans compared to the overhead costs of implementing a stable risk management structure, makes lending too expensive. The costs of lending can only be covered if a large volume of business is achieved. Thus, lenders prefer to look for cheaper techniques that can be used to mitigate risk as alternatives to individual risk assessment. But banks deal with risk-for all

and medium size enterprises (SMEs), while accounting for costs to those enterprises, although not focusing on micro-businesses); see generally Reports on the Observance of Standards and Codes: Accounting \& Auditing, WORLD BANK, http://www.worldbank.org/en/programs/rosc [https://perma.cc/ RQ5J-Q3QH] (last visited Nov. 6, 2017) (reflecting the tension between requiring sufficient and adequate financial information, while attempting to avoid overburdening businesses).

16. See THE WORLd BANK INT'L COMM. ON CREDit RePorting, FACILITATING SME FinANCING THROUGH IMPROVED CREDIT REPORTING, 10-13 (2014), https://openknowledge. worldbank.org/handle/10986/21810 [https://perma.cc/6KVD-G3R3] (providing an analysis on the influence of credit reporting systems in facilitating access to credit for small and medium enterprises). See generally THE WORLD BANK, GENERAL PRINCIPLES FOR CREDIT REPORTING (2011) http://documents.worldbank.org/curated/en/662161468147557554/pdf/70193-2014-CR-General-

Principles-Web-Ready.pdf [https://perma.cc/2NKK-2ZZA] (providing a most frequently used international standard on credit reporting for middle income and developing jurisdictions).

17. See Allen M. Berger, Marco A. Espinosa-Vega, W. Scott Frame \& Nathan S. Miller, Debt Maturity, Risk, and Asymmetric Information, 60 J. FIN. 2895, 2898-2902 (2005) (discussing creditors' use of "firm-specific private information" in assigning risk ratings for determining debt maturity).

18. An increase in the amount and the quality of the information available on micro-businesses (and generally on MSMEs) may be achieved in a number of alternative, additional ways. Most are inevitably linked with formality. Some are voluntary: for example, creation of information databases in chambers of commerce. Some are mandatory: in some jurisdictions, businesses must register and file accounts at the end of each fiscal year.

19. See supra Part IV.B.1. 
lending operations, not just in the case of MSMEs - using aggregated data fed into complex equations that consider the probability of default based on the context and the circumstances of debtors. Arguably, this constitutes the main source of the decision-making process of the banking business at a strategic level. However, by definition, this type of pre-determined, statistical-based approach to lending cannot be a substitute for bespoke, case-by-case assessment of the risk, especially in the case of micro-businesses, whose probability of default depends on many factors, and whose default has deep social implications. It is one of the main tenets of this article that these mechanisms should be complementary. Neither the origination nor the monitoring of credit may be substituted by aggregate data analysis.

This, and the following sections analyze mechanisms used by lenders to deal with the risk assessment of micro-businesses. First, lenders shorten the maturity of loans. ${ }^{20}$ Combined with the small amount lent, this reduces risks associated with the debtor's moral hazard. ${ }^{21}$ Second, they charge higher interest rates to micro-businesses. ${ }^{22}$ Third, it is customary for lenders to require personal guarantees from shareholders, directors, or related parties (in the case of individual entrepreneurs) to bolster their chances of being repaid. Due to the asymmetry in bargaining power, micro-businesses often have little or no option but to accept financing provided under such conditions. ${ }^{23}$

The situation described in the last section and the previous paragraph places many micro-businesses in a difficult situation, with a very narrow working capital and a very limited ability to grow. ${ }^{24}$ But, perhaps more importantly, the use by banks of other risk management devices, instead of a case-by-case risk assessment, undermines one of the most important functions played by the

20. Studies have analyzed how short maturities help alleviate problems associated with risk and asymmetric information. See Hernan Ortiz-Molina \& M.F. Penas, Lending to Small Businesses: The Role of Loan Maturity in Addressing Information Problems, 30 SMALl BuS. ECON. 361, 381-82 (2008) (analyzing small business in the United States and determining that short loan maturities "mitigate the problems associated with borrower risk and asymmetric information"). Other studies have analyzed the relationship between information and maturity. See Douglas W. Diamond, Debt Maturity Structure and Liquidity Risk, 106 Q. J. ECON. 709, 711 (1991) (analyzing how private information may influence a borrower's choice of short-term debt); Raghuram G. Rajan, Insiders and Outsiders: The Choice Between Informed and Arm's-Length Debt, 47 J. FIN. 1367, 1390 (1992) (suggesting that a firm should match its debt maturity to "the revelation of credible, accurate public information").

21. See supra Part IV.C.1.

22. See supra Part IV.B.5. On the face of it, this would seem like a contradiction, because, under normal conditions, interest rates are determined as a function of risk, so the shorter the term to maturity (as opposed to loans provided to larger businesses for longer terms), the lower the interest rate. However, an increase in the interest rate in loans to micro-business also factors in the relatively excessive overhead costs.

23. See discussion infra Part III. In part, as observed in Part III, this explains the fact that bank financing constitutes a relatively low percentage of the overall financing of micro-businesses in almost every region of the planet, including - albeit to a lesser extent - in fully developed jurisdictions.

24. Not surprisingly, the average life of micro-businesses is usually low, even in the most developed economies. See Hanas A. Carder \& John C. Leatherman, Small Business Survival and Sample Selection Bias, 37 SMALL BUS. ECON. 155, 160 tbl.2 (2011) (presenting the frequency of firm deaths in the United States). 
financial sector of any economy: the intermediation function. Banks are supposed to channel the savings of the population to the productive economy by lending the money of depositors to viable businesses. If the assessment of viability is absent precisely where it is most needed (namely, where there are no public sources of relevant information, such as filed audited accounts or market listing), the economy suffers, because the eventual result is likely to be a NPL and the insolvency of a large portion of the micro-businesses. Thus, there will be less money available to lend to viable businesses. Moreover, proper assessment is in the banks' own interests because they can thereby ensure long-term, profitgenerating borrowers, rather than borrowers who cannot pay interest and who generate enforcement costs.

Several measures may be adopted to increase the involvement of banks in the assessment process. First, banks could adopt classic relationship-banking techniques, such as close links between banker and customer, ${ }^{25}$ and the cultivation of a long-term relationship by using short term, repeat lending facilities, such as an overdraft. The consequent increase in the information available would aid banks in assessing risk at a lower cost. Second, banks should ensure that they have an adequate internal organization. Third, they should use the types of secured transactions that align the viability of the business with the value of the collateral, such as floating charges or charges over the going concern value of the business.

\section{The Use of Collateral}

In addition to the risk mitigation techniques mentioned in the last two sections, ${ }^{26}$ lenders are likely to manage the risk of lending to micro-businesses by taking some form of real security. ${ }^{27} \mathrm{~A}$ micro-business is not likely to have the types of fixed assets lenders prefer to be given as collateral, such as real estate. Instead, what is available is movable property, usually circulating assets such as inventory, receivables and cash. A legal system that does not permit security to be taken over such assets ${ }^{28}$ will hamper the availability of credit: what is required is legal reform enabling security to be taken over future assets, while enabling the grantor to dispose of such assets in the ordinary course of business. This also has the advantage, as mentioned earlier ${ }^{29}$ that security is taken over assets whose value aligns with the value of the business, so that monitoring and control of those assets forces the lender to continue to assess the viability of the micro-business throughout the life of the loan.

25. This could relate both to the period before any loan is made, if potential borrowers are account holders, and to the period after the initial loan is made.

26. See supra Parts IV.B.1, IV.B.2.

27. But see infra Parts III.B. (noting an exception to this is the institution of micro-finance, which is unsecured and relationship based).

28. Or one which, for example, requires the specific identification of the assets which are the subject of the security interest in the security agreement.

29. See supra Parts IV.B.1, IV.B.2. 
To get the full benefit of security, the lender must be sure that it will have priority over any other competing claimants to the collateral, and that it can enforce cheaply, quickly, and easily. On the other hand, the small amount of the loan means that, for the loan to be economic for the lender, the costs of taking security must be low. Again, a reformed system of secured transactions law (that is, in line with UNCITRAL's Model $\mathrm{Law}^{30}$ ), which includes a modern, electronic, register of security interests in which registration can be effected online, at a very low fee (merely enough to cover for the cost of maintenance of the Registry), without technicality and in advance of the actual grant of security, and where registration guarantees priority over most competing claimants will enable all of these requirements to be met. Moreover, the system needs to include efficient means of enforcement, including the ability to enforce out of court. This is because court proceedings can be both costly and slow, and the prospect of having to enforce in that way is likely to disincentivize lenders. ${ }^{31}$

While the characteristics of secured transactions law mentioned in the last two paragraphs provide a legal framework in which lenders will be more willing to extend secured credit to micro-businesses, their inclusion in a secured transactions law does also increase the likelihood of adverse consequences for borrowers. If it is possible to take security over circulating assets and intangibles, a lender is likely to over-collateralize, ${ }^{32}$ and the mere fact that the lender is protected by collateral may disincentivize pre-lending due diligence and postlending monitoring. ${ }^{33}$ It is therefore important that taking security is not a substitute for proper individual risk assessment, ${ }^{34}$ but is seen as additional, longstop, protection.

\section{The Use of Guarantees}

As mentioned earlier, guarantees are widely used as a risk management technique in the province of micro-business financing. ${ }^{35}$ The guarantor is usually a specially related party: either a family member, when the main debtor is an individual entrepreneur; or shareholders and directors (if they are different), in the case of legal entities. When lending to micro-businesses, and in the absence of real estate, banks seem to prefer guarantees to security rights over movable collateral,${ }^{36}$ although guarantees can themselves be secured if collateral is

30. See U.N. Commission ON INT'L TRAde L. [UNCITRAL], UNCITRAL Model L. ON SECURED TRANSACTIONS, U.N. Sales No. E.17.V.1 (2016) [hereinafter UNCITRAL MODEL LAw].

31. See infra Part IV.C.3.a.

32. See infra Part IV.D.

33. But see infra Part III.B (noting that depending on the type of collateral, post-lending monitoring may be enhanced).

34. See discussions supra Parts IV.B.1 and IV.B.2.

35. See supra Part III.

36. This is a common finding in the World Bank's Insolvency and Creditor's Rights Regimes Report on the Observance of Standards and Codes (ICR ROSC). Some of these reports may be accessed here: Global Insolvency Law Database, THE WORLD BANK, http://www.worldbank.org/en/topic/ financialsector/brief/global-insolvency-law-database [https://perma.cc/F8J4-SM2N] (last visited Feb. 17, 2018). 
available. In a way, it can be said that guarantees are the "collateral" of the poorer market participants.

A guarantee enhances the assets available for repayment and hence reduces the risk of the bank. But this is not the only, and perhaps not the main, reason why banks commonly request the provision of guarantees. As well as operating as a risk mitigation technique, the provision of guarantees reduces the borrower's moral hazard and therefore the lender's agency costs. Where a micro-business is a legal entity, the personal guarantee of the shareholder or director closely aligns that person's interests with that of the business and incentivizes diligence in its management. In the case of a sole entrepreneur, the giving of a guarantee by a family member reduces the incentives of the borrower to disperse funds to alternative uses, and may incentivize that family member to monitor the operation of the business. ${ }^{37}$ Because these effects cause a reduction in the risk of lending, and hence increase the willingness of lenders to provide finance and, at least theoretically, lower its price, there are sound reasons to protect this lending practice.

However, guarantees may also create undesirable effects. Guarantees render the separation of legal personality between shareholders or directors and the legal entity useless. Limited liability ceases to exist, with all the negative externalities that such loss entails. On the personal side, it is not infrequent that guarantees come from the spouse, parents and other persons closely related to the sole entrepreneur, or even to the shareholder or director of a company. As a consequence, the failure of the micro-business to repay spreads to the guarantor and causes dramatic financial problems for the whole household, and may even generate household insolvency. This may become especially problematic, given the asymmetry in bargaining power, where financial institutions do not behave reasonably in relation to enforcement, and the authorities often do not supervise properly.

Given the positive and negative aspects of the widespread use of guarantees in micro-business financing practice, legislators need to enact regulation that strikes an adequate balance, to the extent that this is possible. In the period before the debtor defaults, it should be possible for a guarantor to set aside a guarantee under the general law only in the case of fraud or other serious abuse such as duress. ${ }^{38}$ Another type of abuse by banks occurs when the following conditions are fulfilled: first, the guarantor is not a shareholder or director of a micro-business nor a sole entrepreneur, in which case he is likely to be a family member or a related person; second, at the time the bank requested and received the guarantee, the guarantor was, on an objective assessment, not in a position to

37. See Douglas G. Baird, Security Interests Reconsidered, 80 VA. L. REV. 2249, 2263 (1994) (analyzing the use of the guarantee mechanism by institutional lenders); Avery Wiener Katz, An Economic Analysis of the Guarantee Contract, 66 U. CHI. L. REV. 47, 70-71 (1999) (suggesting that unlike non-familial guarantors, family members may have additional incentives to monitor, such as a "perceived moral obligation," which may lower a lender's risk).

38. If the guarantor becomes insolvent within a short period of time after giving the guarantee, the guarantee may be able to be set aside under the law relating to avoidance of transactions. 
meet the guaranteed obligation, nor was it objectively probable that he would be in that position during the maturity period of the loan. ${ }^{39}$ In this situation, the guarantee can be seen as taken only to harness the borrower's behavior. The first, ex ante, response to this abuse is that supervisors should actively monitor and act against abusive practices by banks (and the legislation should provide mechanisms for micro-businesses to alert the relevant agency of abusive behavior). The second, ex post, response should only operate when the debtor defaults or is insolvent. Here, it is suggested that a bank should not be able to enforce a guarantee against an individual when the two conditions mentioned above are fulfilled, and when, in addition, the guarantor is not able to pay at the time of enforcement, as the circumstances do not, in isolation, justify enforcement against an individual who will be forced into personal insolvency. ${ }^{40}$ Countervailing factors may, of course, point towards enforcement being permitted in a particular case.

Measures are also necessary when the micro-business is subject to insolvency proceedings. At the very least, rules must be enacted to coordinate the insolvency proceedings, and earlier out of court solutions, relating to the guarantor and the micro-business. ${ }^{41}$ For example, such rules might allow a common filing, assign competence to the same court, appoint one insolvency representative for both insolvencies, and ensure adequate separation of estates. Further, the insolvency system ought to have in place a consistent regime of debt discharge.

\section{Problems Arising from the Process of Contract Formation}

The terms on which the lender provides finance will be contained in the financing agreement, which, in the case of a micro-business, will inevitably be on the standard terms of the lender because the lender is the repeat player, and has by far the greater bargaining power. Moreover, the extensive use of standard term contracts contributes to reducing the transaction costs: negotiation and any resulting variation in terms could tip the cost of the transaction over the level a lender would consider economic. Most micro-businesses, anyway, not only do not have the bargaining power to negotiate, they also do not have the necessary knowledge and sophistication.

This approach is likely to result in a package of terms that are heavily weighted in favor of the lender. These terms normally include both procedural terms, such as limitations in the methods of draw-down and repayment, the

39. This would not apply where the guarantee is secured with collateral, at least to the value of the collateral.

40. See, e.g., Ronald B. Davis, Stephan Madaus, Alberto Mazzoni, Irit Mevorach, Riz Mokal, Justice Barbara Romaine, Janis Sarra \& Ignacio Tirado, A Modular Approach to Micro, Small, and Medium Enterprise Insolvency Chapter VI. 5. C (2018) (unpublished manuscript) (previous version on file at https://papers.ssrn.com/sol3/papers.cfm?abstract_id=2904858 [https://perma.cc/XB75-HGZK]) for a discussion of how the German Constitutional Court (followed by the civil law section of the Supreme Court) has refused to enforce a guarantee given by a related person on these grounds.

41. See David Hahn, Velvet Bankruptcy, 7 THEORETICAL INQUIRIES L. 523, 534-38, 540-42 (2006) (discussing the abuse of personal guarantees for corporate business and how pre-insolvency (and insolvency) law may solve the problem). 
methods whereby the borrower is notified of changes, and how and where disputes are resolved, and substantive terms, such as the level of interest and the level of payments after default, as well as the definition of default itself. Arguably, a restrictive package of terms is a method of keeping financing costs low: flexibility and personalization cost the lender money. Moreover, lenders would argue that high rates of interest, and particularly default interest, reflect the risks undertaken in lending to micro-businesses.

The danger of this approach to micro-businesses is apparent. Many of the terms mentioned are likely to be substantively detrimental to the business. This is substantive unfairness. Moreover, given that standard terms are likely to be in small print and in technical and complicated language, they are likely to be procedurally unfair: the individual running the micro-business probably will not appreciate the content of the terms when he signs the contract. The detrimental effect will only become clear at the stage when the term becomes relevant, at which point the content of the term may well be such as to cause severe damage to the business, and maybe even drive it into insolvency.

Legal techniques exist to tackle procedural unfairness and, to a lesser extent, substantive unfairness. Procedural unfairness can, to some extent, be tackled by mandatory disclosure of information in a prescribed form, including standardized methods of displaying charges so as to aid comparison. While such measures are relatively cheap and straightforward to implement, there is a danger that rigid formality may be counterproductive, especially if the sanction for noncompliance is that the contract is void. This is because a lender may be disincentivized from lending because of the risk that its legal rights against the borrower may be severely reduced if it makes one typographical error. Another technique is to provide that an unfair term is unenforceable by the party relying on it. These techniques are much more developed in relation to consumer contracts than to business contracts. ${ }^{42}$ Although it is not entirely straightforward to apply techniques used in the consumer field to contracts to micro-businesses, there is no technical reason why this cannot be done, provided that the definition of micro-business is robust and the context is made clear.

First, non-financial terms will be considered. These are terms that do not concern interest rates or charges. Here, legislation can apply a standard that addresses both procedural and substantive unfairness. ${ }^{43}$ The substantive test

42. Compare Council Directive 93/13/EEC, art. 3-5, 1993 O.J. (L 95) 29, 31 (EC) (providing guidelines for assessing the unfairness of terms in consumer contracts), with Commission Proposal for a Regulation of the European Parliament of the Council on a Common European Sales Law, art. 86, COM (2011) 635 final (Oct. 11, 2011) (defining "unfair" in business contracts between traders), and Unfair Contract Terms Act 1977, c. 50, § 2-7 (UK) (applying only to limitation and exclusion clauses in business contracts), and common law rules against penalties (whereby a liquidated damages clause can be struck down if it "imposes a detriment on the contract-breaker out of all proportion to any legitimate interest of the innocent party in the enforcement of the primary obligation." See Cavendish Square Holding BV v. Talal El Makdessi [2015] UKSC 67, [32]).

43. See Council Directive 93/13/EEC, supra note 42, at Annex 1(i), art. 3-5 (including as "unfair" those terms which are not individually negotiated, and which cause a significant imbalance in the parties' rights and obligations arising under the contract, to the detriment of the consumer); Unfair Contract 
must, however, be applied in context. Although a term, looked at in isolation, may seem unfair, it must be considered as part of the package, including the cost of borrowing: a lower interest rate may compensate for some flexibility in other areas. Lenders could also argue that in order to make lending to micro-businesses economic, processes need to be rigid and simple, since flexibility is costly. Crafting a legislative test that enables an appropriate weight to be given to these two points is difficult, and the unfairness bar should probably be set reasonably high so as only to target really abusive terms. Further, lenders can argue that the mere fact that a term could be set aside under unfair terms legislation makes lending more uncertain, and therefore more expensive, and less attractive. There is no real answer to this argument, except competition between lenders. A legislative test is no use, however, unless matters can be effectively brought to court. It is extremely unlikely that a micro-business would have the resources to challenge an unfair term in court. The best method is to enable an Ombudsman or other institution, such as a chamber of commerce, to apply to court to have a standard term struck out. ${ }^{44}$

Second, financial terms will be considered. These are in two categories: the regular interest rates and charges, and the position on default. In relation to the former, it can be argued that this is the price for the loan, and that the price must be a matter for the agreement of the parties and the market, so that legislative controls cannot apply to it. On this view, the only control that can be imposed is a procedural one, that is, that the whole amount of the interest (including charges) is made clear to the counterparty in a way that he can understand it and compare it to that offered by other finance providers. A lender is likely to argue that a high interest rate reflects the costs of lending to a micro-business: the very small profit from a low value loan, the proportionately high costs of the transaction and, especially, the extra risk due both to the high credit risk inherent to the characteristics of a micro-business, and to the often very poor debt collection systems. To some extent, a legal regime can mitigate the extra risk if it makes it easy and cheap to take security over all available collateral, and to enforce it properly, although it is not necessarily the case that a reduction in such risk will actually result in a lower interest rate. Proportionately high costs can, to some extent, be reduced by reform of the legal regime, though the need to have a certain level of protection for the borrower will entail some costs. Another response to the charging of high interest rates is to encourage maximum competition among lenders: the lack of competition in the financial sector is one of the real problems in developing and middle income countries, which is externalized on the borrower by means of excessive interest rates.

High rates of interest or other charges, such as penalties or administrative charges, which are imposed on default, are in a different category as they are not

Terms Act, supra note 42, $§ 11$ (assessing reasonableness based upon the circumstances existing when the contract was made).

44. See Consumer Rights Act 2015 c. $15, \S 70$, sch. 3 (UK) (allowing certain organizations to apply for relief). 
part of the price of the loan. High default rates threaten the viability of the business in the event of financial distress and impact on other creditors of the borrower in the ensuing insolvency, rather than on the borrower itself. There is also more likely to be procedural unfairness here. The individual is likely to be aware of the headline rate of interest on the loan but is less likely to be aware of the default rate, which may well be in small print. Even if he is aware of a high default rate, if he needs finance he may agree to it thinking or hoping that default "will never happen."

It is possible to have legislative controls on default rates based on fairness. For example, such controls could require a comparison between the rates charged and the likely actual loss to the lender. However, such controls are likely to produce uncertainty and therefore to disincentivize lending. Increasing competition is less likely to assist in this area, since borrowers are unlikely to be aware of the exact amount of default rates and are not likely to decide which lender to use based on default rates, for the reasons given above. Therefore, other techniques likely to make much inroad on high default rates are either a legislative cap on default rates, such as in Germany or Spain ${ }^{45}$ or action in the insolvency of the micro-business, such as legislative subordination of default interest to the other debts of the micro-business, as in Spain. ${ }^{46}$

\section{The Lifecycle of the Financing Operation}

The special circumstances of micro-businesses do not only create problems in their access to credit; once the financing has been provided, practice shows that both borrowers and lenders often conduct themselves in manners that are suboptimal for the market of credit. The problems that arise during the lifecycle of credit to micro-businesses feed into the ex ante position of the parties, and, unless adequately tackled, may make lending less accessible and more expensive. Due to length constraints, this article shall only refer to a few of those possible problems.

\section{The Behavior of the Debtor}

With any loan, there is a danger that the borrower will allocate the funds to uses other than those for which the financing was provided, or will otherwise act in a way which increases the credit risk from that originally taken on by the lender. In relation to loans to micro-businesses, the techniques set out above partly mitigate the risk of this moral hazard is partly mitigated by the techniques set out above.$^{47}$ However, other techniques commonly used to control against the debtor's moral hazard are often absent. Monitoring by creditors is difficult (in

45. In Spain, the limit has been established by the Law 3/2004 "Of measures to fight against default in commercial transactions", as amended by the Law 31/2014. In Germany, see the interpretation of the Courts of paras. 247 and 288 of their Civil Code (BGB): for more detail on the different types of caps on interest rates, see the commentary in BÜRGERLICHES GESETZBUCH [BGB] [CIVIL CODE], para. 247, 288, (Beck Verlag 77 ed. 2017).

46. See Ley Concursal art. 93 (B.O.E. 2003, 164) (Spain).

47. See supra Part IV.B. 
good part due to the low level of formality and accounting practice) and, as discussed in the next section, uncommon. Lenders provide financing through simple agreements, often templates or basic boilerplate contracts, with no covenants restricting activities that may increase the credit risk, or information covenants creating reporting duties to enable monitoring. Debtors conduct simple businesses, where, particularly but not exclusively in the case of sole proprietors, the separation of assets and liabilities arising from the personal and the business spheres is blurred ${ }^{48}$

The problem of moral hazard becomes more critical as a borrower approaches a business crisis and default has occurred or is about to happen. The general risk, which applies to all borrowers, that any action a borrower takes to avoid or address financial distress in a way which protects creditors' interest will be untimely or inadequate, is much greater in relation to micro-businesses. Micro-businesses tend to be the only source of income for the entrepreneur, and frequently the business involves, in one way or another, several or all members of his family. In this context, debtors put their heads in the sand, go through long periods of negation, and, even after the financial distress has become clearly apparent, delay taking appropriate action.

Frequently, a micro-business will not wish to draw the attention of the bank to its financial distress. Thus, it will not make contact with the bank to discuss its affairs, and will attempt to keep up the payments to the bank while defaulting on payments to other creditors, such as employees or the tax authorities. A debtor will be particularly reluctant for the bank to discover its financial difficulties when the bank has a security right over its assets. ${ }^{49}$ If the security right enables the bank to control the business, either directly or indirectly, on default, the debtor will try to avoid losing it. However, if the collateral is a fixed asset, the debtor will not seek help for fear of losing a key piece of equipment. Something similar happens in unsecured lending by short term, or on-demand, revolving facilities, which often include high default interest rates which a debtor will wish to avoid incurring.

This has the effect that a director or an owner of a distressed micro-business stays in control even when the business is balance sheet insolvent, so that the risk of future loss falls entirely on the creditors. Value destruction almost inevitably

48. In some countries the legal framework sets a division between assets that are acquired and/or used in the context of the business activity, and those that are acquired/used in the personal life of the entrepreneur. Even in these countries, however, all assets are ultimately available to satisfy all creditors, whatever the type of asset or the origin of the debt. See A. MARTINEZ, MiCRO, SMALL AND MEDIUM ENTERPRISES IN AFRICA: A COMPARATIVE STUDY 3 (2017), http://www.uncitral.org/pdf/english/ congress/Papers_for_Programme/135-MARTINEZ-SME_Enterprise_Insolvency_in_Africa.pdf [https://perma.cc/FMG4-3ZTH].

49. A study conducted through interviews and questionnaires with banks showed that small businesses only contact the bank when they are already financially distressed. Before showing its weakness to the financial institution, a debtor will have already adopted measures with their employees (reduction of salaries, suspension of the payment of wages or complements to wages, social security, etc.) or have even stopped paying taxes. See Contractualised Distress Resolution in the Shadow of the Law, CODIRE, https://www.codire.eu [https://perma.cc/J9Z7-PHUP] (last visited Feb. 17, 2018). “ 
follows. Thus, while the measures suggested earlier relating to the initial stages of the credit cycle will mitigate debtor moral hazard, ${ }^{50}$ perhaps the most effective solution would be the inclusion of a system that incentivizes the use of preinsolvency and insolvency systems at an early stage of distress, and one that sanctions late action: a combined set of sticks and carrots. One example of an incentive is to allow the debtor to remain in possession during the restructuring process, because otherwise a debtor would be unwilling to submit to such a process. Another is to include a stay of actions and executions during a negotiation period.

Alas, experience shows that, particularly in the case of family-based microbusinesses, incentives alone are not enough to overcome the fear of losing control of the destiny of the business and of the reputational damage brought about by insolvency and insolvency-related procedures. In the light of this, the legal framework needs to include a duty to act in a way that minimizes damage to creditors from the moment the business is, or is about to be, unable to pay its debts as they fall due. Depending on the legal tradition and of the degree of sophistication of the legal system, either a duty to file for insolvency or a system that makes directors liable for wrongful trading, such as that which operates in common law jurisdictions, ${ }^{51}$ needs to be present. However, because they are finely balanced, actions for wrongful trading are rare and do not always succeed because of the complexity of the rules. Moreover, the system operates on the basis that directors of companies will wish to comply, and will take legal advice as to what is permitted. This works where there are sophisticated market participants, but might be inappropriate for micro-businesses, who are unsophisticated and have few resources for legal advice. Moreover, a director of a micro-business or a sole entrepreneur will have no resources to pay damages. Thus, to provide the correct incentive, a system of sanctions for misbehaving directors and sole entrepreneurs would need to supplement wrongful trading provisions. The alternative, more common in a civil law system, and perhaps more apt in jurisdictions with unsophisticated courts, is the inclusion of a duty to file. While more limited in its scope, the duty to file has the advantage of providing a clear-cut rule for debtors and directors, with no need for an ex post complex analysis of their behavior: something often all but impossible to do given the limited information available in micro-businesses. Moreover, breach triggers sanctions as well as a damages claim. ${ }^{52}$

50. See supra Parts IV.B, IV.C.1.

51. A preference for wrongful trading solutions has now become standard, following its adoption by UNCITRAL. See generally UNCITRAL, UNCITRAL LEGISLATIVE GUIDE ON INSOLVENCY LAW, U.N. Sales No. E.13.V.10 (2013).

52. See Davis supra note 40, at 42-53 (debating the pros and cons of both systems, from the standpoint of MSMEs). 


\section{The Behavior of Lenders}

As mentioned, not infrequently, banks finance micro-businesses without a proper risk assessment based on the viability of the business project. ${ }^{53}$ This passivity is also replicated in the stage that runs from the provision of the funds to the moment of repayment: lenders do not monitor the operation of the microbusiness borrower. Moreover, most financing instruments do not include covenants that oblige borrowers to give information periodically, or restrictive covenants that require borrowers to ask permission to act in a way that adversely affects the risk profile of the loan. ${ }^{54}$ Banks, particularly in developing- and middle-income economies, do not have special departments that monitor businesses during the life of the loan. Small loans to micro-businesses are mainly decided locally, at a branch level, where the main bulk of the activity is commercial, that is, focused on credit-origination. Despite this, it would be possible for a bank to monitor more effectively than described, given that it is in a position to insist that the micro-business holds its current account with that bank, so that the bank is in a unique position to monitor the business's cash flow. Technological advances mean that this monitoring need not require extensive activity by the bank's employees. ${ }^{55}$ The lack of monitoring mentioned above, coupled with the characteristics of micro-businesses, explains why lenders only realize the existence of a problem with the loan when it is already too late.

The behavior of micro-businesses though, is more predictable than the behavior of banks once the financial distress of the debtor has become apparent. The behavior of banks in this situation depends largely on the context. There are, however, common trends.

In jurisdictions with weak banking sectors or countries undergoing, or just emerging from, financial crises, financial institutions often prefer to roll over problem loans in order to avoid increasing the amount of distressed assets (NPLs) in their balance sheet. Forbearing supervisors sometimes overlook this practice, known as ever-greening or zombie lending, and financial institutions frequently do this without taking into account the repayment capacity of the distressed borrower. ${ }^{56}$ Banks also sometimes behave in this way even if the financial sector is not troubled, if the value of the collateral does not depreciate quickly.

53. See discussion supra Part IV.B.2.

54. See supra Part IV.B.1.

55. As mentioned, concerning the origination of credit, banks would substitute monitoring by a statistical analysis of aggregate data. While such practice is indeed relevant, it cannot, by itself, solve the problem created by the lack of monitoring. See supra Part IV.B.2.

56. This happens also in highly sophisticated financial systems, like the Japanese one. In the wake of the economic downturn caused by the great earthquake of 2011, special measures concerning the treatment of NPLs of small and medium size enterprises were adopted. These measures are still in place today, without a clear justification. See generally Ignacio Tirado, Banking Crises and the Japanese Legal Framework (Discussion Paper No 2017-E-2), INST. FOR MONETARY AND ECON. STUD. (2017). 
Banks, however, may also behave in exactly the opposite way in that, on default, they immediately foreclose or enforce any security interests. If there is no collateral, they seize bank accounts or any other identified free asset, as well as calling in the guarantees. They do this without analyzing the debtor's viability, resulting in the near inevitable loss of the going concern value and the destruction of any rescue possibilities that may have existed. ${ }^{57}$ While ever-greening keeps economically distressed micro-businesses alive in an artificial and undesirable manner, this latter approach has the potential to destroy valuable enterprises.

Alternatively, banks may outsource credit recovery to a debt collection agency, wherein a specialized entity, acting as an agent, recovers troubled loans, or banks themselves may sell the portfolio to distressed debt funds. Such sales tend to involve loans that are long overdue or whose recovery has been attempted several times unsuccessfully, and are priced at a very large discount. Unlike a bank, which may benefit from future business with the borrower, a debt collection agency or distressed debt fund does not have any incentive to restructure the loan or to engage in negotiations that may lead to the preservation of the value of a rescuable business. The sale of loans, often regarded as good banking practice because it cleans banks' balance sheets, nevertheless has potential to destroy business value.

Another issue that needs to be addressed concerns the behavior of banks within insolvency proceedings, which in a broad sense, includes hybrid restructuring proceedings. Here, banks often behave passively: they do not engage in negotiations, or may even decline to participate or to vote on insolvency plans. This is particularly the case in relation to MSMEs, and even more so with micro-businesses. All too often, the lack of participation of the bank, characteristically a large creditor in relative terms, may hinder the rescue of viable businesses..$^{58}$

Some of the problems described earlier in this subsection may be addressed by legislative and institutional action. On the preventive side, an early warning system may be implemented. This measure has been expressly included in the EU Directive Proposal on Restructuring and Second Chance of November $2016,{ }^{59}$ and there are already examples in some jurisdictions. ${ }^{60}$ Drawing from the design of bank resolution systems, where an early identification of the problem is paramount, an early warning system consists in stipulating certain objective

57. This applies to the general seizure of assets or to enforcement/foreclosure over assets, but does not necessarily apply where there is a floating charge or any other type of security that makes the preservation of the going concern value of the business possible.

58. See Davis et al., supra note 40, at 70-122 (providing a thorough analysis of bank participation in the insolvency of MSMEs).

59. Commission Proposal for a Directive of the European Parliament and of the Council on Preventative Restructuring, Insolvency and Discharge Procedures and Amending Directive 2012/30/EU, at 39, COM (2016) 723 final (Nov. 22, 2016) [hereinafter Commission Proposal].

60. Denmark has created a platform of early detection and prompt action through social advisers, economic experts and lawyers that help distressed micro-businesses. See Early Warning - Experiences from Denmark, EARLY WARNING, http://startvaekst.dk/earlywarning.dk/earlywarning_experiences _from_denmark [https://perma.cc/VM87-N3K7] (last visited Nov. 26, 2017). 
events. Such events may include default in payments to employees or social security contributions or tax debts. The occurrence of these events alerts creditors and triggers possible remedies. Debtors, and, maybe, third parties such as accountants, could be incentivized or mandated to report such events to the lender. ${ }^{61}$ Apart from providing banks with clearly identifiable signs of financial distress, the inclusion of these triggers is likely to alter the behavior of debtors described earlier, ${ }^{62}$ so that debtors will be more willing to default early on bank debt. This may have an impact in the cost of lending that needs to be assessed.

The supervision of the financial sector should also be addressed. One possibility is to increase supervisory control over banks' management of their loan portfolios. Another area where effective measures may be adopted relates to the regulation of insolvency proceedings. Default rules that sanction disinterest may tackle problems of creditor passivity in out-of-court hybrid workouts or in formal insolvency proceedings. For example, there could be a rule whereby creditors that do not object to their insolvency entitlements may not later allege a different set of rights. Another possible rule would be that creditors who do not participate in voting in relation to a plan are deemed to have approved it. ${ }^{63}$

\section{Collection and Enforcement}

The need to keep transaction costs low because of the low value of loans also impacts on the way in which a lender can enforce on default. Enforcement needs to be cheap and simple: this can be achieved by a combination of reform to legal rules and development of suitable infrastructure.

If a loan is secured, the lender will have a right to enforce against the collateral. If not, or if the collateral is not sufficient, the lender will have to obtain a court judgment and then enforce it through the system for execution of judgments. Each of these will be examined in turn below.

a. Secured lending. One of the benefits of secured lending is that the lender can look to the asset for payment of the secured obligation on default. In the absence of security over an asset, the lender has to obtain a court judgment, and enforce against the borrower's assets. If, however, a secured lender must use court proceedings in order to enforce against assets, this particular advantage of secured lending is lost. Although it depends upon the system, court proceedings usually add cost and delay. In a handful of countries it is possible to obtain a court order within a very short period of time and in the absence of the borrower. In other systems, undoubtedly the majority in developing and middle-income countries, but even common in some developed jurisdictions, borrowers abuse the procedural system with endless appeals: they postpone hearings, for example,

61. See Commission Proposal, supra note 59, at 27.

62. See supra Part IV.C.1 (describing the tendency of debtors to default on obligations to their employees or to tax authorities before defaulting on bank or supplier debt).

63. See Davis et al., supra note 40, at 20-29,30-39 for a further explanation of these principles and their justification, expressly for the case of micro-businesses. 
by not coming to court or ignoring notices. Additionally, court fees are high, and judges tend to observe a pro-debtor tendency that severely hampers an efficient collection. While, in the first case, court proceedings add relatively little to the time and cost of enforcement, in the more common context, court proceedings are a very considerable cost in terms of time and money.

There are four possible complementary approaches to this issue. The first is to improve the court infrastructure to minimize the time and money costs of court proceedings relating to enforcement. A second approach would be to streamline the law on procedure by limiting the ability of the parties to challenge ancillary elements of the procedure, such as the appointment of appraisers; restricting the need for court hearings; and ensuring there are very limited grounds for reopening the court decision. ${ }^{64}$ In line with this, the use of court proceedings could be limited to where there is a real dispute between the parties, for example, where the borrower alleges a good arguable defense to the claim of default. The third approach is for the legal system to permit, and maybe provide, alternative means of resolving disputes or of heading off further disputes, such as binding alternative dispute resolution which is only open to very limited court challenge. The fourth is for the legal system to permit out of court enforcement, because this can usually be carried out far more quickly and cheaply than enforcement via the courts, although this will depend on the points made earlier. However, a system of out of court enforcement needs to include some protection for the debtor: this often takes the form of a notification system before possession is taken or other enforcement takes place, restrictions on the ability of the enforcing creditor to go onto the debtor's premises, rules preventing the enforcing creditor from causing a breach of the peace, and some sort of general standard of good faith or reasonableness applying to the whole process. ${ }^{65}$ While these protections are even more important in the case of a micro-business, and particularly of an individual, that is vulnerable to oppressive conduct, protections such as those mentioned make the process more uncertain and costly. A balance, therefore, needs to be found between the need for a simple and cheap out of court enforcement process, and a reasonable level of protection for the debtor. ${ }^{66}$

b. Unsecured lending. If the loan is not secured, officers, who are often appointed and supervised by the court, perform enforcement, rather than the creditor itself. First, there needs to be some process whereby a judgment, or equivalent, is obtained so that the enforcement officers can be instructed. Again, for a low value debt owing by a micro-business, obtaining such an order needs to be a quick and cheap process. Although a reformed court system could effect

64. In the case of micro-businesses, the use of "bad lawyering" to forestall proceedings is less frequent, precisely because of the defendant's lack of resources to use expensive lawyers. However, the problem is often acute when it comes to notifications.

65. See discussion infra Part IV.C.3.d (discussing measures specifically relating to enforcement against individuals).

66. It is worth noting that micro-finance institutions hardly ever sue in court. Their collection mechanisms are usually out of court. 
this, ${ }^{67}$ alternatively, the system could permit a binding decision to be made using alternative dispute resolution mechanisms, including online mechanisms. Again, some provision would need to be made for the protection of the debtor such as proper notification of the decision making process and a right to be heard, and it should not be possible to contract out of this protection. The precise balance between the simplicity and cheapness of the system, and the protection of the debtor will vary according to the circumstances. For example, it could be possible to reduce costs by effective use of technology rather than by reducing the level of debtor protection, especially in those jurisdictions where technology is available. Second, once an order is obtained, there needs to be an efficient infrastructure of (probably) court appointed officers who, as repeat players, can carry out enforcement effectively, but at low cost.

c. Secondary markets. Most of the assets available for enforcement, whether of secured or unsecured lending to micro-businesses, will be tangible, and therefore potentially illiquid, assets. It is thus critical that there is some kind of a secondary market in which these goods can be sold. Lack of such markets will make these assets less useful as collateral, and will disincentivize lending. There are now innovative ways in which such markets exist, or can be created, such as online auctions. While these markets can, and do, arise in the private sector, it is also possible for the government to create a market specifically for the sale of collateral. Of course, a certain level of economic activity is required in a state to enable such a market to work, and the costs of virtual markets for tangibles may outweigh their usefulness. Moreover, some minimum protection is still required for debtors and junior creditors to ensure that goods are not sold at artificially low prices, though the level of protection needs to be kept fairly low, such as with a duty of good faith, if the costs of sale are not to eat up too much of the value of the asset.

d. Special considerations concerning individual debtors. On default by a micro-business, enforcement is often going to be against the assets of an individual, either as sole entrepreneur or guarantor. Unlike a corporate business, whose assets are purely business assets, the assets of a sole entrepreneur are both business and personal, while those of a guarantor are solely personal. ${ }^{68}$ Enforcement against personal assets raises a number of issues. The issues are the same whether the debt is secured against, inter alia, the personal assets or unsecured, although where the debt is unsecured, enforcement will be by a court appointed officer, as mentioned above. ${ }^{69}$

67. See supra IV.C.3.a.

68. An individual could conceivably have assets relating to a separate business other than the one whose debts are guaranteed.

69. See supra Part IV.C.3.b. 
First, if enforcement were permitted against all the personal assets of an individual debtor, whether or not that individual were in bankruptcy proceedings, the debtor, and maybe his family, would be left with nothing on which to live. This is likely to lead to social unrest, so, as a matter of policy, most states provide for certain exempt goods against which enforcement cannot be made, as well as a limited amount of the individual's future income. ${ }^{70}$ While this reduces the assets available for creditors, and, therefore, could disincentivize lending, such provisions are important, both on humanitarian grounds, and because, usually, exempt goods will include tools or other goods used in the individual's trade or profession. Thus, despite the failure of the micro-business the individual ran or guaranteed, she will still be able to either find work or even to start a new business. This will prevent the individual and her family from being reliant on whatever assistance is provided by the state, if any, for those who cannot afford to live. The precise boundaries of what counts as exempt goods will depend, both on the context of that particular state and its population, and on the balance thought necessary to be struck between protecting individuals and, therefore, society, and encouraging lending by permitting as full a recovery as possible. Second, the procedure for enforcement against the personal assets of an individual needs to be somewhat different from that used for enforcement against businesses.

\section{The Institutional Framework}

The previous sections have identified some of the institutional problems that affect the financing of micro-businesses, especially concerning enforcement and insolvency. But the institutional framework plays a very relevant role throughout the entire life-cycle of credit: from its origination to its situation on the verge of and within insolvency proceedings, the financial regulation and its supervision greatly influence the behavior of the parties and hence, ultimately, the validity of the system.

As noted, the regulatory and supervisory frameworks find themselves in an inherent conflict with other relevant interests existing in the market. Central banks and financial supervisors have as their objective the protection of the financial sector, and the rules they draft concerning financial institutions, compliance with which they also monitor, reflect this. The focus of the rules is on financial institutions as debtors, and, therefore, mainly concerns their solvency. ${ }^{71}$ In the light of this, regulations, and the consequent supervision, tend to strengthen the financial positions of regulated and supervised institutions. On the other side of the equation, though, lie borrowers (in our case, micro-businesses).

70. See, e.g., ZIVILPROZESSORDNUnG [ZPO] [CODE OF CIVIL PROCEDURE] § 850 (Ger.); LEY DE ENJUiCIAMIENTO CIVIL [L.E. CIV.] [CODE OF CIVIL PROCEDURE] art. 605 (Spain).

71. By this we mean to include the regulation referred to the lending and investment activity of banks. This is the case because the financial regulator observes this part of the balance sheet of banks from the perspective of the risk of bank themselves. In other words, rules and supervision are aimed often at ensuring a proper management of the assets of the supervised entities, with no regard to the situation of the borrowers. The concern is about the solvency of banks. 
The harder the capital requirements however, the tougher the provisioning rules, the tighter the requirements for the provision of credit to distressed but viable smaller entities, the higher the chances that viable micro-businesses will end up strangled and dead, and, with them, an important part of the productive economy. Overprotecting financial institutions is a mistake. It undermines the general, non-financial, economy and, in the mid- to long-term, harms the financial position of financial institutions themselves by reducing their business. Here, as in so many parts of this article, a balance needs to be struck. Due to length constraints, only some of the most serious examples of this conflict will be mentioned. In doing this, regulation and supervision will be dealt with separately, although this division is somewhat artificial.

From a regulatory standpoint, most countries require lenders to operate a proper risk management system, according to which lending should be made after a thorough analysis of the viability of the business borrower. This is standard good banking. ${ }^{72}$ However, not infrequently, regulations also include strong capital requirements: loans and financing facilities to micro-businesses need to have an initial percentage of provisioning, and the use of collateral is required or at least strongly advised. Due to the general characteristics of micro-businesses, this requirement often cannot be met. Although more developed systems have a more relaxed attitude towards the lack of collateral, financial regulators in other systems forbid the provision of financing to micro-businesses unless collateral is provided. In the most extreme cases, the collateral needs to be land or something similar. The problem is not only that collateral is mandatory, or that movable collateral is not accepted as a valid risk mitigating factor, but also that the framework does not relax its strict provisioning rules at any point in the life cycle of credit, especially when there are signs of distress when security over movable assets is provided. ${ }^{73}$ Another area where the regulatory framework is unfriendly, not only to micro-businesses, but to MSMEs generally, concerns the rules applicable when the borrower is in financial distress. Some jurisdictions have rules that forbid or hinder banks from providing financing to troubled businesses, either through out of court or hybrid work-outs or as part of formal insolvency proceedings. ${ }^{74}$ This occurs despite the fact that the law provides for lenders of new money to have a priority status and even where the debtor or its insolvency representative offers fresh collateral. Restricting post-commencement finance simply destroys any possibility for viable businesses to be rescued. Another common regulatory problem is the inability of a bank to reclassify distressed loans for regulatory purposes when the borrower has reached an out of court agreement or an in-court insolvency plan, even though it is clear that this rescue

72. See generally BASEL COMM. ON BANKING SUPERVISION, PRINCIPLES FOR THE SOUND MANAGEMENT OF OPERATIONAL RISK 11-17 (2011) (outlining standard risk management principles).

73. Concerning the relationship between capital requirements and secured transactions (as a mechanism to reduce risk), see Giuliano G. Castellano \& Marek Dubovec, Credit Creation: Reconciling Legal and Regulatory Incentives, 81 LAW \& CONTEMP. PROBS., no. 1, 2018, at 63.

74. See, e.g., Ley de Instituciones de Crédito [LIC] [Credit Institutions Law] art. 65, 1990, 2016 (Mex.). 
can be implemented. Given these strict rules, banks have little or no incentive to collaborate in restructuring viable businesses.

The main problems, however, lie not with the regulatory framework itself, but with its application. Supervisors tend to be lenient in relation to overcollateralization, or even directly promote it. Naturally, the more collateral taken to secure the debt, the lower banks' risk. Because of the asymmetry of bargaining power and the scarce availability of credit for micro-businesses, banks can impose financing operations with loan-to-value ratios well beyond $100 \%$. The less developed the jurisdiction and the less competitive the market, the more this is the case. Demanding collateral greatly in excess of the credit provided has the potential to cause substantive damage to the economy, particularly in developing and middle income jurisdictions. It affects businesses that have fewer assets to provide as collateral more severely, because, on the one hand, it hampers their ability to access new financing, and tends to generate undesirable social implications. On the other hand, third parties and family members are likely to have to provide collateral. "Overcollateralization" is less problematic in countries with a long-standing tradition of financing over all the business's assets and with well-functioning institutions. In these systems, overcollateralization of the most senior lender does not necessarily bring about a reduction in credit because a new lender may take second charges over the same assets. While this is true in almost all jurisdictions, second (successive) charges over the same asset only work properly when the transaction and enforcement costs are low. Otherwise, every time a creditor enforces its security right, the value of the collateral is diminished to a greater extent than the cancellation of the previous debt, and substantive money is lost in the whole enforcement process, in terms of both cost and of time.

Demanding excessive collateral requirements is not in accordance with proper banking practice, and it should be censured by supervisors. The failure of supervisors to do this is caused by the narrow focus on the short-term interest of their supervised institutions. Supervisors ought instead to act in pursuit of the general interest, there should be better coordination between financial authorities and the relevant ministries: economy, trade, and development.

As mentioned earlier, ${ }^{75}$ it is relatively common, particularly in developing jurisdictions and in countries lacerated by financial crises, that banks reschedule loans almost as a matter of custom, without assessing the future viability of the business. This ever-greening is a wrongful practice. It manipulates the financial accounts of banks, and it deprives the system of a filter to identify viable, rescuable financially distressed businesses. Just as banks ought to assess risk at the onset of the lending operation, so should they get involved in the restructuring of their viable borrowers. But the practice of ever-greening is only one external sign of the more worrying tendency of banks to be passive in relation to their portfolio of loans to micro-businesses. Banks simply do not bother to sit

75. See supra Part IV.C.2. 
down with borrowers to renegotiate in cases of financial, rather than economic, distress. From a financial regulatory standpoint, this problem may be tackled mainly by two types of actions: first, the jurisdiction ought to have a code of conduct mandating sufficient involvement of banks in the distress of smaller debtors; second, supervisors must enforce such code of conduct. Enforcement often necessitates a static and a dynamic component: supervisors must make sure that banks have in place the necessary infrastructure to execute the task, such as specialized teams, restructuring departments, a standardized and streamlined flow of information between the disparate sections of the bank. They must also conduct inspections and create communication channels with micro-businesses to receive complaints of misbehavior.

\section{$\mathrm{V}$ \\ CONCLUSION}

Micro-businesses are important throughout the world, both economically and as major employers. They have special characteristics which make it difficult for them to access finance and, when finance is granted, affect the behavior of the parties over the lifecycle of credit from origination, through its use in the business, to repayment or default. This article seeks to map out the main issues that arise in the life cycle of credit for micro-businesses, and to suggest possible legal and institutional solutions.

One must bear in mind that there is an inherent tension between solutions designed to increase access to finance and those designed to protect microbusinesses and individuals. This tension is evidenced both at the level of each of the separate issues discussed in the article and in relation to the way in which the responses to the various issues relate to each other. Thus, for example, permitting easy and cheap access to collateral incentivizes lenders not to perform sufficient due diligence and monitoring. If the latter is addressed by regulation, this may raise costs making lending to micro-businesses less attractive economically. These are just examples. There are interrelationships between all the issues raised and between the possible legislative responses to those issues. In designing legislative responses, therefore, the tensions must be identified and decisions taken as to the correct balance.

The actual decisions as to balance are, of course, a matter of policy and depend enormously on the context and the state of the market. All that can be done here is to suggest the approaches that could be taken to make those decisions. Applying the correct approach, however, is critical; it is as important as tackling the issues in the first place. 